\title{
The determination of the clay content of soil by a semi-micro variation of the Robinson method
}

\author{
Ali Beverwijk \\ Scientific Department, IJsselmeerpolders Development Authority, Kampen, \\ the Netherlands
}

Received: 13 June 1972

\section{Summary}

The determination of the clay content of soil can be carried out with reasonable accuracy employing a semimicro variation of the Robinson method. Although it is slightly less reliable than the macromethod, the standard deviation being between 1.3 and 1.9 times as great, the results are sufficiently close to those obtained by the macromethod to be acceptable. In this investigation $95 \%$ reliability was achieved with only minor exceptions. Reliability and accuracy will increase as greater experience is acquired.

When processing is continuous some $50 \%$ more determinations can be made in a given time with the semimicro- than with the macromethod.

As in the case of the macromethod, a correction has to be applied for the residue of salt remaining in the suspension after the electrolyte has been siphoned off.

\section{Introduction}

The laboratory of the IJsselmeerpolders Development Authority in Kampen, like many laboratories in the Netherlands and abroad, uses Robinson's gravimetric pipette method, referred to here as the macromethod (Hofstee, $1966 \mathrm{a}, \mathrm{b}$ ), to determine the clay content of soil. The examination of a sample takes 5 days, and if processing is continuous 24 determinations of the fractions $0-2 \mu \mathrm{m}$ and $0-16 \mu \mathrm{m}$ can be completed by each person per day. Experience has shown that the method is reliable and accurate, but it is important to investigate whether there are quicker methods which will also provide the required measure of precision and reliability. The Laboratory for Soil and Crop Testing at Oosterbeek uses a method it has developed which is a semimicro variation of the Robinson method, referred to here as the micromethod, and which enables some $50 \%$ more determinations to be made over a given period than the macromethod we use. It is thus worthwhile comparing the two methods.

This article summarizes the results of an extensive comparative investigation which was carried out in our laboratory into a number of types of Dutch soils with widely differing particle sizes. Standard deviations were calculated from a number of groups of samples as a measure of reproducibility (Hofstee and Verhoeven, 1962).

\section{Procedure}

Micromethod

Pre-treat $20 \mathrm{~g}$ of soil ( $40 \mathrm{~g}$ in the case of sand samples) with $\mathrm{H}_{2} \mathrm{O}_{2}$ and $\mathrm{HCl}$ to remove organic matter, $\mathrm{CaCO}_{3}$ and other cohesive components. Peptize the soil with $\mathrm{Na}_{4} \mathrm{P}_{2} \mathrm{O}_{7}$ 
and, after homogenizing, determine the $0-2 \mu \mathrm{m}$ and $0-16 \mu \mathrm{m}$ clay fractions gravimetrically.

\section{Macromethod}

Pre-treat $3 \mathrm{~g}$ of soil $\left(6 \mathrm{~g}\right.$ in the case of sand samples) with $\mathrm{H}_{2} \mathrm{O}_{2}$ and $\mathrm{HCl}$ to remove organic matter, $\mathrm{CaCO}_{3}$ and other cohesive components. Peptize the soil with $\mathrm{Na}_{4} \mathrm{P}_{2} \mathrm{O}_{7}$ and, after homogenizing, determine the $0-2 \mu \mathrm{m}$ and $0-16 \mu \mathrm{m}$ clay fractions gravimetrically.

\section{Results}

The following conclusions can be drawn from the processed analysis results derived from samples originating from the IJsselmeer area as set out in Table 1.

The micromethod gives a higher standard deviation for both fractions than the macromethod. In the case of both methods the deviation for $0-16 \mu \mathrm{m}$ is somewhat higher than for $0-2 \mu \mathrm{m}$. This is understandable when one remembers that the mixture from which the $0-16 \mu \mathrm{m}$ fraction is pipetted, having had a short sedimentation time, and therefore containing a higher concentration of clay particles, must be more sensitive to disturbance caused by the introduction of the pipette than the mixture from which the $0-2 \mu \mathrm{m}$ fraction is pipetted, which has had a long sedimentation time. The shape and capacity of the sedimentation cylinder also influence the results. In the case of the micromethod the circumstances referred to will be far more liable to give rise to higher standard deviations than in the case of the macromethod. This becomes apparent when the same samples are analysed a second time by the micromethod, using a modified clay pipette. The outlet tube (approximate external $\varnothing 6 \mathrm{~mm}$ ) is made thinner by attaching to it an $8 \mathrm{~cm}$ long injection needle (external $\phi 2 \mathrm{~mm}$ ) thus restricting to a minimum the disturbance caused in the suspension by the introduction of the pipette. The injection needles available commercially, however, have a bevelled, and hence elliptical, outlet; this should be sawn off horizontally before the needle is fixed to the pipette, as an elliptical outlet can cause air bubbles to be drawn in during the pipetting. Determinations carried out with this pipette produce results for which the standard deviation is considerably lower than when a normal pipette is used (Table 1). In the case of the $0-16 \mu \mathrm{m}$ fraction the figure was the same as that obtained by the macromethod.

With the micromethod the standard deviation for samples of various nature (Table 2) - calculated for increasing content groups - was at the same level as that for the

Table 1. Standard deviations calculated from twin determinations of the clay content of 18 Dutch samples from the IJsselmeer area.

\begin{tabular}{|c|c|c|c|c|c|}
\hline \multirow[t]{3}{*}{ Method } & \multirow[t]{3}{*}{$0-2 \mu \mathrm{m}(\%)$} & \multicolumn{4}{|c|}{ Standard Deviation } \\
\hline & & \multicolumn{2}{|c|}{$\emptyset$ outlet tube approx. $6 \mathrm{~mm}$} & \multicolumn{2}{|c|}{$\varnothing$ outlet tube $2 \mathrm{~mm}$} \\
\hline & & $0-16 \mu \mathrm{m}$ & $0-2 \mu \mathrm{m}$ & $0-16 \mu \mathrm{m}$ & $0-2 \mu \mathrm{m}$ \\
\hline Macro & $30-40$ & 0.85 & 0.46 & - & - \\
\hline Micro & $30-40$ & 1.04 & 0.88 & 0.85 & 0.65 \\
\hline
\end{tabular}


Table 2. Standard deviations calculated from twin determinations of the clay content of Dutch samples (number $=\mathbf{n}$ ) of various nature.

\begin{tabular}{|c|c|c|c|c|c|}
\hline \multirow[t]{3}{*}{$0-16 \mu \mathrm{m}(\%)$} & \multirow[t]{3}{*}{$0-2 \mu \mathrm{m}(\%)$} & \multicolumn{4}{|c|}{ Standard Deviation } \\
\hline & & \multicolumn{2}{|l|}{$0-16 \mu \mathrm{m}(\%)$} & \multicolumn{2}{|l|}{$0-2 \mu \mathrm{m}(\%)$} \\
\hline & & macromethod & micromethod & macromethod & micromethod \\
\hline $0-20$ & $0-20$ & $0.43 \mathrm{n}=54$ & $0.53 \mathrm{n}=52$ & $0.38 \mathrm{n}=95$ & $0.72 \mathrm{n}=85$ \\
\hline $20-50$ & $20-30$ & $0.53 \mathrm{n}=127$ & $0.74 \quad n=124$ & $0.51 \mathrm{n}=112$ & $0.68 \mathrm{n}=104$ \\
\hline$>50$ & $30-40$ & $0.64 \mathrm{n}=167$ & $0.81 \mathrm{n}=148$ & $0.55 \mathrm{n}=139$ & $0.80 \mathrm{n}=129$ \\
\hline
\end{tabular}

IJsselmeer samples in the case of the 0-16 $\mu \mathrm{m}$ fraction and somewhat less satisfactory in the case of the $0-2 \mu \mathrm{m}$ fraction. As will become apparent later, this outcome must be ascribed to the present lack of experience in carrying out the analysis, which sometimes causes fairly considerable differences between the twin determinations.

The standard deviations, not included in the tables, which were obtained when very young sediments from the land reclamation projects in the north of the Netherlands were examined by the micromethod, correspond more or less to the values obtained with samples from the IJsselmeer area. However, the $<25 \% 0-2 \mu \mathrm{m}$ group fell just outside the $95 \%$ reliability figure, which was not the case with the samples in Table 2. The explanation for this must lie in the fact that an exceptionally large number of very light soils were included in the analysis samples from the land reclamation areas and the discrepancies between the twin determinations for such soils are usually substantial.

Experience with the micromethod has shown that even minor shortcomings in the carrying out of the analyses can have a detrimental effect on the results and that the laboratory staff must be very well acquainted with the analysis techniques if the standard deviation is to remain at an acceptable level (Table 3). It has also become clear that the reproducibility of the microdetermination increases if $3 \mathrm{~g}$ of soil are taken instead of $2 \frac{1}{2} \mathrm{~g}$. Where, as in the case of very light soils, the samples are naturally very heterogeneous, better results will be obtained by using $6 \mathrm{~g}$ instead of $3 \mathrm{~g}$ for the analysis. A double quantity of such soils is also taken for the macrodetermination.

Earlier research (Beverwijk, 1963) showed that the value obtained when the clay content was determined by the macromethod had to be corrected to allow not only for the quantity of peptizer present in the suspension, but also for the salt residue

Table 3. Standard deviations calculated from twin determinations of clay content of 199 Dutch samples of various nature.

\begin{tabular}{lllll}
\hline Method & \multicolumn{2}{l}{ Standard Deviation } & \\
\cline { 2 - 4 } & \multicolumn{2}{l}{ with experience of technique } & & $\frac{\text { without experience of technique }}{0-16 \mu \mathrm{m}}$ \\
\cline { 2 - 4 } & $0-16 \mu \mathrm{m}$ & $0-2 \mu \mathrm{m}$ & & $0-2 \mu \mathrm{m}$ \\
Macro & 0.55 & 0.49 & - & - \\
Micro & 0.73 & 0.68 & 0.98 & 0.88 \\
\hline
\end{tabular}


remaining in the suspension after the electrolyte has been siphoned off. The salt residue correction factor required was found to average $3 \mathrm{mg}$. The micromethod also requires a correction factor for the salt residue as well as for the peptizer. Experiments have shown that the salt residue correction factor for the micromethod should be $2 \mathrm{mg}$.

The results of the investigation described above have led to the introduction of the micromethod for the determination of clay content, and this method is now successfully employed in our laboratory; 35 determinations of the $0-2 \mu \mathrm{m}$ and $0-16 \mu \mathrm{m}$ fractions can now be carried out in the same time as 24 determinations by the macromethod. Further experience in the analysis technique is expected to result in a higher reproducibility than it was possible to achieve in this investigation.

\section{Acknowledgment}

The author is grateful to the management of the Laboratory for Soil and Crop Testing at Oosterbeek for making details available to her of the analysis method used there.

\section{References}

Beverwijk, A., 1963. Het effect van de toevoeging van $\mathrm{CaCl}_{2}$ bij de sliblutumbepaling aan van nature kalkloze of nagenoeg kalkloze monsters en de invloed hiervan op de zoutzuurconcentratie. [The effect of the addition of $\mathrm{CaCl}_{2}$ in the determination of $<2 \mu \mathrm{m}$ particles in naturally lime-free or nearly lime-free silt samples and its influence on the hydrochloric acid concentration.] Intern Rapport 3784, IJsselmeerpolders Development Authority.

Beverwijk, A., 1971. De bepaling van het kleigehalte in grondmonsters volgens een semi-micro variant van de methode Robinson. [The determination of the clay content of soil samples by a semi-micro variation of the Robinson method.] Intern Rapport 259, IJsselmeerpolders Development Authority.

Hofstee, J., 1966a. Analysemethoden voor grond, gewas, water en bodemvocht in gebruik bij het Bodemkundig Laboratorium van de Rijksdienst voor de IJsselmeerpolders. [Methods of analysing soils, plants, water and soil moisture used in the Soil Laboratory of the IJsselmeerpolders Development Authority.] IJsselmeerpolders Development Authority, Kampen.

Hofstee, J., 1966b. Toelichting op de analysemethoden yoor grond, gewas, water en bodemvocht in gebruik bij het Bodemkundig Laboratorium van de Rijksdienst voor de IJsselmeerpolders. [Explanatory notes on the methods of analysing soils, plants, water and soil moisture used in the Soil Laboratory of the IJsselmeerpolders Development Authority.] IJsselmeerpolders Development Authority, Kampen.

Hofstee, J. \& B. Verhoeven, 1962. Gegevens betreffende de betrouwbaarheid van het grondonderzoek in het IJsselmeergebied. [Data concerning the reliability of soil analysis in the IJsselmeer area.] Flevoberichten, IJsselmeerpolders Development Authority, Zwolle, A No 30. 